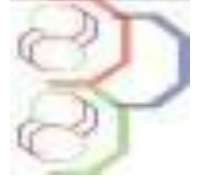

Journal of Applied Biosciences 157: 16223 - 16236

ISSN 1997-5902

\title{
The Togolese Medicinal Recipe, Diabeto-Dolvo® Exerted Antidiabetic Effects in Wistar Rats
}

\begin{abstract}
Holaly Efui Gbekley¹, Kokou Idoh², Nassifatou Titikpina ${ }^{3}$, Kodjovi Agbodeka ${ }^{1}$, Kokou Anani',

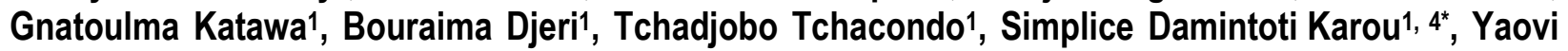
Ameyapoh', Simpore Jacques 4 .

1. Ecole Supérieure des Techniques Biologiques et Alimentaires (ESTBA-UL), Université de Lomé, Togo.

2. Laboratoire de Physiologie et de Pharmacologie, Faculté des Sciences (FDS-UL) Université de Lomé, Togo.

3. Laboratoire de Botanique et Ecologie Végétale Faculté des Sciences (FDS-UL) Université de Lomé, Togo.

4. $\quad$ Centre de Recherche de Biologie Moléculaire Pietro-Annigoni (CERBA) Ouagadougou, Burkina-Faso.

Correspondence: Karou Damintoti Simplice, Ecole Supérieure des Techniques Biologiques et Alimentaires (ESTBAUL), Université de Lomé, 01 BP 1515, Lomé 01, Togo. Email: simplicekarou@hotmail.com
\end{abstract}

Original submitted in on 24 $4^{\text {th }}$ November 2020. Published online at www.m.elewa.org/journals/ on $31^{\text {st }}$ January 2021 https://doi.org/10.35759/JABs.157.8

\begin{abstract}
Objective: this study was to evaluate the toxicity of a herbal recipe Diabeto-Dolvoß (DD) and its efficacy in streptozotocin-induced diabetic Wistar rats.

Methodology and results: The toxicity test was performed by oral administration of the extract to rats while diabetes was induced with streptozotocin, the 250 , and $500 \mathrm{mg} / \mathrm{kg}$ body weight. The results of the toxicity tests revealed no evidence of mortality or morbidity suggesting an LD50 greater than $5000 \mathrm{mg} / \mathrm{kg}$. Similarly, the biochemical and haematological parameters remained unchanged. In antidiabetic tests, there was a progressive decrease followed by a normalization of the glucose level of the treated rats. Overall, the extract at 250 and $500 \mathrm{mg} / \mathrm{kg}$ body weight resulted in a significant reduction in glycated haemoglobin, amylase, lipase, G6PD and serum lipids.

Conclusion and application of results: This study revealed that, the treatment with the recipe might repair oxidative damages, hyperglycaemia and hyperlipidaemia in diabetic rats in the same way as the treatment with glibenclamide. This study is a contribution to the experimental validation of the DD recipe. In research and development application, the DD recipe will be used in the treatment of cases of diabetes mellitus. A natural product, it will support the multiple treatments of so-called conventional medicine, relatively expensive for the population.
\end{abstract}

Key words: Diabeto-Dolvo®; blood glucose; oxidative damage; streptozotocin; diabetes mellitus; Togo.

\section{INTRODUCTION}

Diabetes mellitus is a disorder linked with severe insulin dysfunction in conjugation with abnormalities in glucose and lipid metabolism, affecting several million people in the world. The disease often occurs either when the pancreas does not produce enough insulin or when the body cannot effectively use the insulin it produces, insulin being the hormone that regulates blood sugar. Hyperglycaemia is a common effect of uncontrolled diabetes and over time leads to serious damage to many of the body's systems, especially the nerves and blood vessels (WHO, 2017). Hence, the 
diabetic patients are at risk of blindness, renal failure, and amputation because of gangrene and, in some cases risk of cardiovascular diseases (WHO, 2017). There is also evidence that free radicals are implicated in the aetiology of diabetes (Alamdari et al., 2017). Oxidative stress plays an important role in diabetes mellitus since its genesis to the stage of microvascular disorders (Johar and Bernstein, 2017). The generation of free radicals in diabetes is due to glucose auto-oxidation. This is linked to glycosylation of proteins and glycosylated proteins are known to be a source of free radicals (Yazdanpanah et al., 2017). Until recently, the control of diabetes was only insulin-based therapy, occasioning some resistance to insulin. Presently, some plant extracts have been introduced in the fighting against diabetes (Porqueddu, 2017). Many ethnobotanical studies have been conducted to identify the plants used in traditional medicine for the treatment of diabetes (Karou et al., 2011; Gbekley et al., 2015). To date a reliable database exists on antidiabetic plants; however, a small number has received special attention in laboratory screening. It should be noted that among the few plants tested in laboratories, many have yielded promising results (Giribabu et al., 2014; Attanayake et al., 2016; Oguntibeju et al., 2016). Consequently, there is a continuous gap in proper understanding the mode of action of several medicinal recipes

\section{MATERIALS AND METHODS}

Drugs and reagents: Streptozotocin was purchased from Sigma-Aldrich (USA), glibenclamide from DENK PHARMA GmbH \& Co. KG (Germany). Human® biochemical kits provided the reagent kits for the measurement of blood biochemical data.

The recipe: A sample of the recipe DD was supplied from the manufacturer, a traditional healer in Lomé (Togo). For laboratory analysis, the recipe was reconstituted with the authorization of the manufacturer as follows: leaves of Caesalpinia bonduc (25\%), leafy stem of Momordica charantia (25\%), leaves of Phyllanthus niruri (25\%) and fruits of Xylopia aethiopica (25\%). The plants samples were collected on June 2016 in the maritime region of Togo in the presence of the traditional healer. The identification of the plants was performed at the department of Botany of the University of Lomé (respective voucher numbers 2799, 151, 3367, because traditional medicines generally lacked scientific explanations (Leonti et al., 2017). Many plant extracts are known to repair oxidative damages. This may be beneficial in the management of several diseases including diabetes (Calcabrini et al., 2017). It is also known that some natural formulations are more active than their purified compounds (Sabu and Kuttan, 2002; Kpodar et al., 2016). So it becomes imperative to focus on traditional recipes to verify their effectiveness. This has a double interest. First, the scientist is closer to what is done in the traditional medicine. Secondly, the native recipe no longer needs additional treatment if it is effective because the populations already use it as it is (Edorh et al., 2015; Ahama-Esseh et al., 2017). This study aimed to evaluate the effect of the hydro alcoholic extract of a recipe, Diabeto-Dolvo® (DD) on streptozotocin (STZ)-induced diabetes in rats. The recipe DD was supplied from the manufacturer, a traditional healer in Lomé, who participated in a previous study conducted to identify the medicinal plants used in the management of diabetes in the maritime region of Togo (Gbekley et al., 2015). Diabeto-Dolvo $®$ and related recipes were further included in a study conducted for the assessment of hygienic quality of some antidiabetic recipes collected in the same region (Gbekley et al., 2017).

and 1987 for Momordica charantia, Caesalpinia bonduc, Phyllanthus niruri and Xylopia aethiopica). The samples were dried in the laboratory at room temperature under permanent ventilation and then ground to powder prior to Diabeto-Dolvo® reconstitution.

Assessment of the physicochemical parameters of Diabeto-Dolvo®: Diabeto-Dolvo $\cap$ was examined for the colour, taste, texture, odour and its behaviour in several conditions like in water, in $\mathrm{H}_{2} \mathrm{SO}_{4}$, in $\mathrm{KOH}$, in $\mathrm{FeCl}_{3}$, in Dragendorff's solution and in $\mathrm{KI}+\mathrm{I}_{2}$. Further, the $\mathrm{pH}$ of the recipe was determined by dissolving the recipe in distilled water $(10 \%)$ and measuring the $\mathrm{pH}$ with a pHmeter. The dry matter was estimated by desiccation at $110^{\circ} \mathrm{C}$ until constant weight.

Preparation of Extracts: Extraction was performed by percolation of the recipe with ethanol $70 \%$ (v/v) ambient temperature for 2 days. The crude hydro-alcoholic 
extract was filtered on Whatman filter paper $\mathrm{N}^{\circ} 1$ and concentrated under reduced pressure to dryness. The dry residue was stored at $4^{\circ} \mathrm{C}$ until use.

Phytochemical analysis: Total phenols were assayed using Folin-Ciocalteu reagent $(50 \%, v / v)$ as recommended by Singleton et al. (1999). The test was performed in tubes at a final volume of $2 \mathrm{~mL}$ with gallic acid as standard. Absorbance was measured at $760 \mathrm{~nm}$ with a Unico model $1200 \mathrm{E}$ spectrophotometer. All tests were done in duplicate. Proanthocyanidins were assayed by the butanol / $\mathrm{HCl}$ method with catechin as standard as described by (Makkar, 1999). The test was carried out in the tubes at a final volume of $8 \mathrm{~mL}$ and the absorbance at $550 \mathrm{~nm}$ was measured.

Determination of antioxidant activity: The free radical scavenging capacity of the extract was assayed by the phosphomolybdenum assay with ascorbic acid as standard as described by Prieto et al. (1999). The test was performed in tubes at a final volume of $6 \mathrm{~mL}$ and the absorbance was measured at $820 \mathrm{~nm}$.

Animals: Wistar rats, male and female of 2 and 3 months, weighing 200-250 g and 150-200 g, respectively, were provided by the Animal Care of the Ecole Supérieure des Techniques Biologiques et Alimentaires (ESTBA-UL) at the University of Lomé, Togo. They were maintained in standard conditions (22$24 \circ \mathrm{C}$; light/dark cycle L: D: 12:12), with water and dry food ad libitum. The experimental protocols were based on the Organization for Economic Cooperation and Development guideline for the care and use of laboratory animals (https://grants.nih.gov/grants/olaw/Guide-forthe-Care-and-Use-of-Laboratory-Animals_Prepub.pdf)

and were approved by the Committee for Animal Experimentation Ethics of ESTBA-UL $\left(\mathrm{N}^{\circ}\right.$ 0001/201604/ESTBA-UL)

\section{Toxicity tests}

Acute toxicity: For the test, the rats were fasted overnight, but with free access to water. The extract was dissolved in distilled water and administrated orally. Animals were divided in tree groups of five both male and of female. The first group received distilled water. Groups 2 and 3 received the extract, 2500 and 5000 $\mathrm{mg} / \mathrm{kg}$, respectively. Afterwards, animals were observed for a period of 14 days.

Sub-acute toxicity: The animals were divided into three groups as described in the acute toxicity test. The first groups considered as control received distilled. The groups II and groups III received the extract 250 or 500 $\mathrm{mg} / \mathrm{kg} / \mathrm{day}$ for 28 consecutive days. Body weight and food consumption and water intake were daily monitored. At the end of the treatment, animals were anesthetized with ether, and blood samples were taken by retro-orbital puncture for haematological and biochemical studies. Haematological analysis was performed with whole blood samples collected in EDTA impregnated tubes using an automatic haematological analyser (Coulter STKS, Urit 3000 Plus, China). Biochemical analysis was performed on serum obtained from blood in anticoagulant free tubes centrifuged at $4000 \times \mathrm{g}$ for $10 \mathrm{~min}$. Dosages were made using spectrophotometry (Urit $囚$ and Sinnova $®$, China).

Determination absolute and relative organ weights. : After the animals were anesthetized and euthanized, the organs were carefully removed for macroscopic examination and the weigh. Organ weights were expressed in absolute $(\mathrm{g})$ and relative weight calculated as follows.

Relative weight $=\frac{\text { organ weight }(\mathrm{g})}{\text { total body weight }(\mathrm{g})} \times 100$

Antidiabetic test: Streptozotocin (STZ) was dissolved in $0.1 \mathrm{M}$ sodium citrate buffer ( $\mathrm{pH} 4.5)$. The rats were fasted overnight; afterwards they received intra peritoneal injections of $50 \mathrm{mg} / \mathrm{kg}$ body weight STZ. They were the allowed to drink $5 \%$ glucose solution overnight. Control rats were injected with citrate buffer. After 7 days, the rats having glycosuria and blood glucose above $250 \mathrm{mg} / \mathrm{dl}$ were considered as diabetic. The treatment started on the $15^{\text {th }}$ day after STZ injection and monitored for 28 days. The animals were divided into five groups of six animals. Groups I and II were normal control rats and diabetic control rats, respectively; groups III and IV received $250 \mathrm{mg} / \mathrm{kg}$ body weight/day and $500 \mathrm{mg} / \mathrm{kg}$ body weight/day, respectively and group $\mathrm{V}$, diabetic rats treated with glibenclamide $5 \mathrm{mg} / \mathrm{kg}$ body weight/day.

Determination of biochemical parameters: After 28 days of treatment, the rats were sacrificed by cervical decapitation. Blood was collected in tubes. Glycated haemoglobin and glucose-6-phosphate dehydrogenase (G6PD) levels were estimated using the whole blood. The estimation amylase, lipase, triglycerides, totalcholesterol, HDL cholesterol, LDL- Cholesterol was determined as described above.

Statistical Analysis: Statistical analyses were performed with PRISM 5 (Graph Pad Software, Inc., La Jolla, USA) using Two-way RM ANOVA with Bonferroni post tests for glucose level during the treatment in the groups. The other data were analysed using KruskalWallis test and Dunn's Multiple Comparison Test. The statistical significance was set at $P<0.05$. 


\section{RESULTS}

Physicochemical aspect of Diabeto-Dolvo®: The results of the examination of the Diabeto-Dolvo® recipe were as follows: Green dry smooth powder with strong spicy odour and bitter taste. In water, the recipe produces a pale straw coloured turbid solution. In 5\% $\mathrm{KOH}$ solution its gives a brown coloured turbid solution. In $5 \% \mathrm{H} 2 \mathrm{SO} 4$ solution, it is a pale straw coloured turbid solution. In $\mathrm{FeCl} 3$ solution, the powder settles at the bottom and a few particles remain suspended giving a dark brown supernatant. In Dragendorff's solution, the powder settles again at the bottom and turns black giving a clear orange brown supernatant. Finally, in $\mathrm{KI}+12$ solution, it settles at the bottom and turns black giving a clear brown supernatant. The $\mathrm{pH}$ of the aqueous suspension of the recipe was 4.80 . The dry matter of the recipe was $99.22 \pm 0.24 \%$.

Phenolics contents and scavenging activity: The amounts of total phenolics and proanthocyanidins in the extract were $50.83 \pm 1.46 \mathrm{mg}$ Gallic acid equivalent and $101.61 \pm 2.27 \mathrm{mg}$ of catechin equivalent per gram of extract. The reduction of molybdates revealed that the extract was equivalent to $111.51 \pm 0.42 \mathrm{mg}$ of Ascorbic Acid / g. Thus, DD recipe could be considered as a phenolic rich recipe with important free radical scavenging activity.

Toxicity of the extract: In the acute toxicity, no deaths or hazardous signs were recorded in rats during 14 days of observation after acute treatment by oral route with recipe in dose of 2500 and $5000 \mathrm{mg} / \mathrm{kg}$. Similarly, in the sub-acute mode, no toxicity signs or deaths were recorded during the 28 consecutive days of treatment by oral route with extract in doses of 250 and $500 \mathrm{mg} / \mathrm{kg}$. In addition, no significant changes were recorded in body weight gain by comparison between the control and treated rats (Figures 1 and 2).

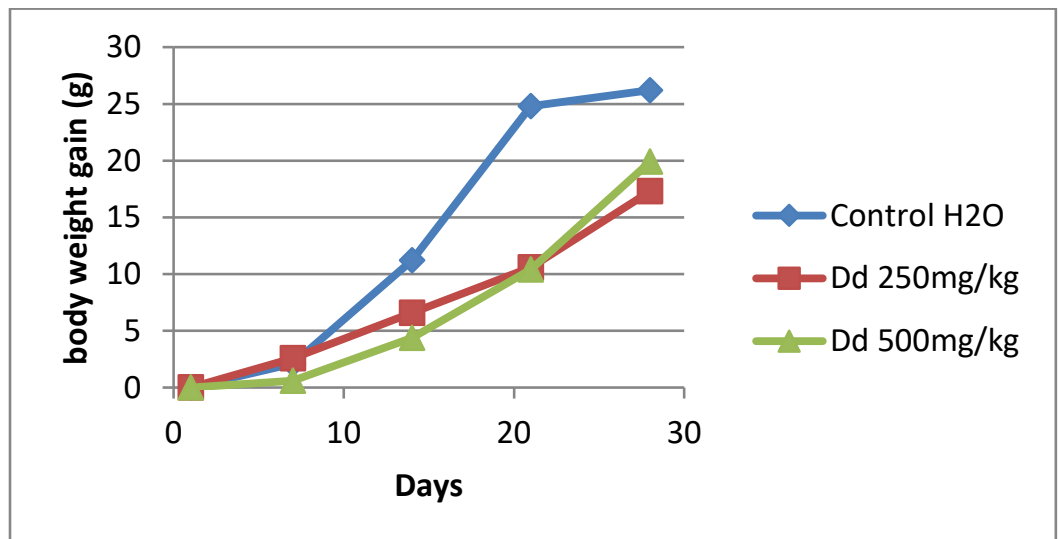

Figure 1. Body weight gain curves of male rats treated orally with the Diabeto-Dolvo® recipe by oral route for 28 consecutive days.

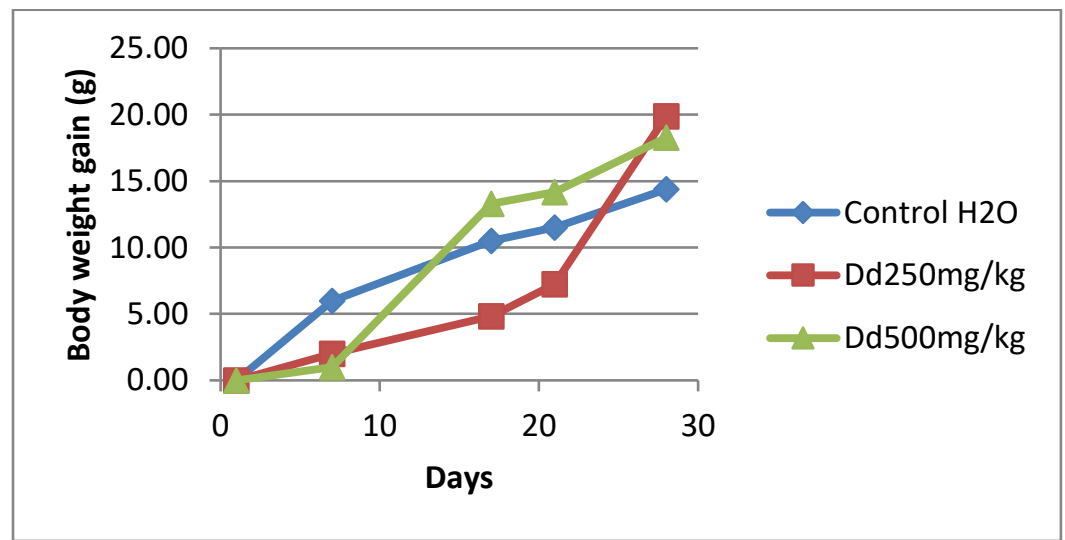

Figure 2. Body weight gain curves of female rats treated orally with the Diabeto-Dolvo® recipe by oral route for 28 consecutive days. 
Similarly, the absolute weights and the relative weights of the organs did not vary significantly in comparison with the organs of the control rats (tables 1 and 2). Data from the blood analysis revealed that the haematological parameters were not altered overall. There was a significant increase in granulocyte percentage in male rats (tables 3 and 4); however, there was no significant difference in their count. Data from the biochemical analyses revealed in males a significant dose-dependent increase in $\gamma$-Glutamyl Transferase ( $\gamma G T$ ) (table 5). There was also a significant increase in alkaline phosphatase in the group of rats treated with $500 \mathrm{mg} /$ $\mathrm{kg}$ dose of extract. However, this increase is not dosedependent because there was no significant increase in this parameter in $250 \mathrm{mg} / \mathrm{kg}$ administered rats. The other parameters remained unchanged compared to the control group. Similarly, in female rats there was a significant increase in the yGT level (table 6). There was also a significant change in LDL-cholesterol levels. Nevertheless, this does not appear to be dosedependent since the increase was recorded with the treated group at $250 \mathrm{mg} / \mathrm{kg}$, while there was a decrease in the upper dose group. These results suggested that the extract could interfere with normal liver function by increasing the level of blood yGT. However, it would not interfere with normal functioning of the kidney and would not affect blood electrolytes such as sodium, potassium and chlorine.

Table 1: Organ weight in male Wistar rats treated orally with the Diabeto-Dolvo® recipe by oral route for 28 consecutive days

\begin{tabular}{l|l|l|l|l}
\hline \multirow{2}{*}{ Organs } & Weight & Control $\mathrm{H}_{2} \mathbf{O}$ & $\mathbf{2 5 0} \mathbf{~} \mathbf{g} / \mathbf{k g}$ & $\mathbf{5 0 0} \mathbf{~ m g} / \mathbf{k g}$ \\
\hline \multirow{2}{*}{ Kiver } & Absolute $(\mathrm{g})$ & $5.970 \pm 1.775$ & $3.914 \pm 1.828$ & $4.319 \pm 0.303$ \\
\cline { 2 - 5 } & Relative $(\mathrm{g} / 100 \mathrm{~g})$ & $4.854 \pm 1.443$ & $2.988 \pm 1.395$ & $3.085 \pm 0.216$ \\
\hline \multirow{3}{*}{ Spleen } & Absolute $(\mathrm{g})$ & $0.697 \pm 0.131$ & $0.536 \pm 0.067$ & $0.570 \pm 0.073$ \\
\cline { 2 - 5 } & Relative $(\mathrm{g} / 100 \mathrm{~g})$ & $0.567 \pm 0.107$ & $0.409 \pm 0.051$ & $0.407 \pm 0.052$ \\
\hline \multirow{2}{*}{ Heart } & Absolute $(\mathrm{g})$ & $0.438 \pm 0.129$ & $0.319 \pm 0.172$ & $0.368 \pm 0.031$ \\
\cline { 2 - 5 } & Relative $(\mathrm{g} / 100 \mathrm{~g})$ & $0.380 \pm 0.105$ & $0.244 \pm 0.131$ & $0.263 \pm 0.022$ \\
\hline \multirow{2}{*}{ Lungs } & Absolute $(\mathrm{g})$ & $0.652 \pm 0.087$ & $0.486 \pm 0.143$ & $0.581 \pm 0.073$ \\
\cline { 2 - 5 } & Relative $(\mathrm{g} / 100 \mathrm{~g})$ & $0.530 \pm 0.071$ & $0.371 \pm 0.109$ & $0.415 \pm 0.052$ \\
\hline \multirow{3}{*}{ Testicles } & Absolute $(\mathrm{g})$ & $1.171 \pm 0.230$ & $0.940 \pm 0.215$ & $1.163 \pm 0.502$ \\
\cline { 2 - 5 } & Relative $(\mathrm{g} / 100 \mathrm{~g})$ & $0.952 \pm 0.187$ & $0.718 \pm 0.164$ & $0.831 \pm 0.359$ \\
\hline \multirow{2}{*}{ Seminal vesicles } & Absolute $(\mathrm{g})$ & $0.734 \pm 0.319$ & $0.754 \pm 0.401$ & $0.759 \pm 0.199$ \\
\cline { 2 - 5 } & Relative $(\mathrm{g} / 100 \mathrm{~g})$ & $0.597 \pm 0.259$ & $0.576 \pm 0.306$ & $0.542 \pm 0.142$ \\
\hline \multirow{2}{*}{ Vas deferens } & Absolute $(\mathrm{g})$ & $1.320 \pm 0.253$ & $1.183 \pm 0.143$ & $1.040 \pm 0.060$ \\
\cline { 2 - 5 } & Relative $(\mathrm{g} / 100 \mathrm{~g})$ & $1.073 \pm 0.206$ & $0.903 \pm 0.109$ & $0.743 \pm 0.043$ \\
\cline { 2 - 5 } & Absolute $(\mathrm{g})$ & $0.576 \pm 0.013$ & $0.596 \pm 0.092$ & $0.461 \pm 0.293$ \\
\cline { 2 - 5 } & Relative $(\mathrm{g} / 100 \mathrm{~g})$ & $0.468 \pm 0.011$ & $0.455 \pm 0.075$ & $0.329 \pm 0.659$ \\
\hline
\end{tabular}

Table 2: Organ weight in female Wistar treated orally with the Diabeto-Dolvo@ recipe by oral route for 28 consecutive days

\begin{tabular}{l|l|l|l|l}
\hline \multirow{2}{*}{ Organs } & Weight & Control $\mathrm{H}_{2} \mathrm{O}$ & Dd 250 $\mathbf{~ g} / \mathbf{k g}$ & Dd 500 $\mathbf{~ g} / \mathbf{k g}$ \\
\hline \multirow{3}{*}{ Liver } & Absolute $(\mathrm{g})$ & $5.943 \pm 0.062$ & $3.634 \pm 0.431$ & $4.222 \pm 0.075$ \\
\cline { 2 - 5 } & Relative $(\mathrm{g} / 100 \mathrm{~g})$ & $4.795 \pm 0.050$ & $2.931 \pm 0.333$ & $3.609 \pm 0.064$ \\
\hline \multirow{3}{*}{ Spleen } & Absolute $(\mathrm{g})$ & $0.576 \pm 0.002$ & $0.620 \pm 0.017$ & $0.644 \pm 0.007$ \\
\cline { 2 - 5 } & Relative $(\mathrm{g} / 100 \mathrm{~g})$ & $0.465 \pm 0.001$ & $0.500 \pm 0.014$ & $0.550 \pm 0.006$ \\
\hline \multirow{2}{*}{ Heart } & Absolute $(\mathrm{g})$ & $0.353 \pm 0.003$ & $0.369 \pm 0.068$ & $0.433 \pm 0.169$ \\
\cline { 2 - 5 } & Relative $(\mathrm{g} / 100 \mathrm{~g})$ & $0.285 \pm 0.002$ & $0.298 \pm 0.055$ & $0.370 \pm 0.144$ \\
\hline \multirow{2}{*}{ Lungs } & Absolute $(\mathrm{g})$ & $0.545 \pm 0.006$ & $0.405 \pm 0.002$ & $0.496 \pm 0.004$ \\
\cline { 2 - 5 } & Relative $(\mathrm{g} / 100 \mathrm{~g})$ & $0.440 \pm 0.004$ & $0.327 \pm 0.002$ & $0.424 \pm 0.003$ \\
\hline \multirow{2}{*}{$\begin{array}{l}\text { Female genital } \\
\text { organs }\end{array}$} & Absolute $(\mathrm{g})$ & $1.251 \pm 0.007$ & $1.067 \pm 0.152$ & $1.194 \pm 0.143$ \\
\cline { 2 - 5 } & Relative $(\mathrm{g} / 100 \mathrm{~g})$ & $1.009 \pm 0.005$ & $0.860 \pm 0.123$ & $1.021 \pm 0.122$ \\
\cline { 2 - 5 } & Absolute $(\mathrm{g})$ & $0.450 \pm 0.012$ & $0.346 \pm 0.001$ & $0.355 \pm 0.010$ \\
\cline { 2 - 5 } & Relative $(\mathrm{g} / 100 \mathrm{~g})$ & $0.363 \pm 0.010$ & $0.279 \pm 0.001$ & $0.303 \pm 0.009$ \\
\hline
\end{tabular}


Table 3. Haematological profile of male Wistar rats after 28 consecutive days administration of extract.

\begin{tabular}{|c|c|c|c|}
\hline Parameters & Control $\mathrm{H}_{2} \mathrm{O}$ & DD 250 mg/Kg & DD 500 mg/Kg \\
\hline WBC (109/L) & $8.30 \pm 2.79$ & $8.46 \pm 3.24$ & $9.30 \pm 2.41$ \\
\hline LYM\% & $61.18 \pm 6.20$ & $61.48 \pm 8.80$ & $68.34 \pm 2.90$ \\
\hline MID\% & $11.38 \pm 3.46$ & $14.38 \pm 5.28$ & $12.28 \pm 2.58$ \\
\hline GRAN\% & $27.44 \pm 4.96$ & $24.14 \pm 3.94$ & $19.38 \pm 1.55^{*}$ \\
\hline LYM (109/L) & $5.02 \pm 1.57$ & $5.08 \pm 1.66$ & $6.32 \pm 1.53$ \\
\hline MID (109/L) & $1.02 \pm 0.61$ & $2.14 \pm 2.73$ & $1.18 \pm 0.47$ \\
\hline GRAN (109/L) & $2.26 \pm 0.88$ & $2.06 \pm 1.04$ & $1.80 \pm 0.48$ \\
\hline $\operatorname{RBC}\left(10^{12} / \mathrm{L}\right)$ & $7.27 \pm 0.68$ & $6.18 \pm 0.35$ & $6.84 \pm 0.46$ \\
\hline $\mathrm{HGB}(\mathrm{g} / \mathrm{dL})$ & $15.58 \pm 0.54$ & $15.20 \pm 0.98$ & $15.98 \pm 0.79$ \\
\hline $\operatorname{HCT}(\%)$ & $34.70 \pm 4.40$ & $29.54 \pm 1.75$ & $32.93 \pm 2.24$ \\
\hline MCV (fL) & $47.72 \pm 1.65$ & $47.92 \pm 1.02$ & $47.76 \pm 0.85$ \\
\hline $\mathrm{MCH}(\mathrm{pg})$ & $21.48 \pm 1.28$ & $24.58 \pm 0.95$ & $23.34 \pm 0.96$ \\
\hline $\mathrm{MCHC}(\mathrm{g} / \mathrm{dL})$ & $45.20 \pm 3.89$ & $51.44 \pm 2.19$ & $49.04 \pm 2.47$ \\
\hline RDW-CV (\%) & $13.80 \pm 0.71$ & $14.02 \pm 0.64$ & $14.02 \pm 0.83$ \\
\hline RDW-SD (fL) & $28.02 \pm 2.28$ & $28.02 \pm 1.52$ & $27.34 \pm 0.76$ \\
\hline PLT (109/L) & $421.80 \pm 98.58$ & $415.00 \pm 131.48$ & $444.40 \pm 30.66$ \\
\hline MPV (fL) & $6.98 \pm 0.42$ & $6.90 \pm 0.31$ & $7.06 \pm 0.39$ \\
\hline PDW (fL) & $7.80 \pm 0.48$ & $8.00 \pm 0.61$ & $8.46 \pm 0.72$ \\
\hline PCT $(\%)$ & $0.29 \pm 0.06$ & $0.28 \pm 0.08$ & $0.31 \pm 0.02$ \\
\hline P_RGC (109/L) & $15.30 \pm 1.55$ & $15.06 \pm 1.97$ & $16.84 \pm 2.88$ \\
\hline P_LCC $(10 \% / L)$ & $62.40 \pm 11.01$ & $60.20 \pm 15.40$ & $74.00 \pm 11.00$ \\
\hline
\end{tabular}

WBC, White Blood Cell Count ; LYM\%, Lymphocyte Percent ; MID\%, Monocyte Percent ; GRAN\%, Granulocyte Percent ; LYM, Lymphocyte Count ; MID, Monocyte Count ; GRAN, Granulocyte Count ; RBC, Red Blood Cell Count ; HGB, Haemoglobin Concentration ; HCT, Haematocrit (relative volume of erythrocytes) ; MCV, Mean Corpuscular Volume ; MCH, Mean Corpuscular Haemoglobin ; MCHC, Mean Corpuscular Haemoglobin Concentration ; RDW-CV, Red Blood Cell Distribution Width repeat precision ; RDW-SD, Red Blood Cell Distribution Width STDEV ; PLT, Platelet Count ; MPV, Mean Platelet Volume ; PDW, Platelet Distribution Width ; PCT, Plateletcrit.

Table 4. Haematological profile of female Wistar rats after 28 consecutive days administration of extract.

\begin{tabular}{l|l|l|l}
\hline Parameters & Control $\mathrm{H}_{2} \mathrm{O}$ & DD $250 \mathrm{mg} / \mathrm{Kg}$ & DD $500 \mathrm{mg} / \mathrm{Kg}$ \\
\hline WBC (109/L) & $8.30 \pm 2.79$ & $8.46 \pm 3.24$ & $9.30 \pm 2.41$ \\
LYM\% & $61.18 \pm 6.20$ & $61.48 \pm 8.80$ & $68.34 \pm 2.90$ \\
MID\% & $11.38 \pm 3.46$ & $14.38 \pm 5.28$ & $12.28 \pm 2.58$ \\
GRAN\% & $27.44 \pm 4.96$ & $24.14 \pm 3.94$ & $19.38 \pm 1.55$ \\
LYM (10\%/L) & $5.02 \pm 1.57$ & $5.08 \pm 1.66$ & $6.32 \pm 1.53$ \\
MID (109/L) & $1.02 \pm 0.61$ & $2.14 \pm 2.73$ & $1.18 \pm 0.47$ \\
GRAN (10\%/L) & $2.26 \pm 0.88$ & $2.06 \pm 1.04$ & $1.80 \pm 0.48$ \\
RBC (1012/L) & $7.27 \pm 0.68$ & $6.18 \pm 0.35$ & $6.84 \pm 0.46$ \\
HGB (g/dL) & $15.58 \pm 0.54$ & $15.20 \pm 0.98$ & $15.98 \pm 0.79$ \\
HCT (\%) & $34.70 \pm 4.40$ & $29.54 \pm 1.75$ & $32.93 \pm 2.24$ \\
MCV (fL) & $47.72 \pm 1.65$ & $47.92 \pm 1.02$ & $47.76 \pm 0.85$ \\
MCH (pg) & $21.48 \pm 1.28$ & $24.58 \pm 0.95$ & $23.34 \pm 0.96$ \\
MCHC (g/dL) & $45.20 \pm 3.89$ & $51.44 \pm 2.19$ & $49.04 \pm 2.47$ \\
RDW-CV (\%) & $13.80 \pm 0.71$ & $14.02 \pm 0.64$ & $14.02 \pm 0.83$ \\
RDW-SD (fL) & $28.02 \pm 2.28$ & $28.02 \pm 1.52$ & $27.34 \pm 0.76$ \\
PLT (10\%/L) & $421.80 \pm 98.58$ & $415.00 \pm 131.48$ & $444.40 \pm 30.66$ \\
MPV (fL) & $6.98 \pm 0.42$ & $6.90 \pm 0.31$ & $7.06 \pm 0.39$ \\
PDW (fL) & $7.80 \pm 0.48$ & $8.00 \pm 0.61$ & $8.46 \pm 0.72$ \\
\hline
\end{tabular}




\begin{tabular}{l|l|l|l}
\hline PCT $(\%)$ & $0.29 \pm 0.06$ & $0.28 \pm 0.08$ & $0.31 \pm 0.02$ \\
P_RGC (109/L) & $15.30 \pm 1.55$ & $15,06 \pm 1,97$ & $16.84 \pm 2.88$ \\
P_LCC $(10 \% / L)$ & $62.40 \pm 11.01$ & $60.20 \pm 15.40$ & $74.00 \pm 11.00$ \\
\hline
\end{tabular}

WBC, White Blood Cell Count ; LYM\%, Lymphocyte Percent ; MID\%, Monocyte Percent ; GRAN\%, Granulocyte Percent ; LYM, Lymphocyte Count ; MID, Monocyte Count ; GRAN, Granulocyte Count ; RBC, Red Blood Cell Count ; HGB, Haemoglobin Concentration ; HCT, Haematocrit (relative volume of erythrocytes) ; MCV, Mean Corpuscular Volume ; MCH, Mean Corpuscular Haemoglobin ; MCHC, Mean Corpuscular Haemoglobin Concentration; RDW-CV, Red Blood Cell Distribution Width repeat precision ; RDW-SD, Red Blood Cell Distribution Width STDEV ; PLT, Platelet Count ; MPV, Mean Platelet Volume ; PDW, Platelet Distribution Width ; PCT, Plateletcrit.

Table 5: Biochemical profile of male rats after 28 consecutive days administration of extract.

\begin{tabular}{|c|c|c|c|}
\hline Parameters & Control $\mathrm{H}_{2} \mathrm{O}$ & DD $250 \mathrm{mg} / \mathrm{kg}$ & DD $500 \mathrm{mg} / \mathrm{kg}$ \\
\hline Urea $(\mathrm{mg} / \mathrm{dL})$ & $70.68 \pm 15.70$ & $77.14 \pm 1.96$ & $63.03 \pm 4.46$ \\
\hline Glycemi a(mg/dL) & $113.99 \pm 15.05$ & $114.67 \pm 6.76$ & $111.27 \pm 18.32$ \\
\hline Creatinin $(\mathrm{mg} / \mathrm{dL})$ & $5.19 \pm 0.08$ & $5.56 \pm 0.35$ & $5.98 \pm 0.21$ \\
\hline Uric Acid (mg/dL) & $5.14 \pm 0.74$ & $5.05 \pm 0.79$ & $5.72 \pm 0.52$ \\
\hline GOT (IU/L) & $124.27 \pm 21.84$ & $121.35 \pm 13.82$ & $156.27 \pm 18.38$ \\
\hline GPT (IU/L) & $118.13 \pm 38.95$ & $105.72 \pm 29.19$ & $81.39 \pm 3.71$ \\
\hline GGT (IU/L) & $2.02 \pm 0.32$ & $4.65 \pm 0.47^{* *}$ & $6.45 \pm 0.37^{* *}$ \\
\hline Pal (IU/L) & $449.97 \pm 1.32$ & $416.25 \pm 69.55$ & $786.07 \pm 88.64^{* *}$ \\
\hline Total bilirubin (mg/dL) & $0.76 \pm 0.06$ & $0.80 \pm 0.02$ & $0.81 \pm 0.03$ \\
\hline Direct bilirubin $(\mathrm{mg} / \mathrm{dL})$ & $0.40 \pm 0.05$ & $0.52 \pm 0.08$ & $0.43 \pm 0.15$ \\
\hline Total protein $(\mathrm{g} / \mathrm{dL})$ & $6.30 \pm 0.26$ & $7.09 \pm 0.11$ & $7.63 \pm 0.64$ \\
\hline Albumin (g/dL) & $4.87 \pm 0.58$ & $4.80 \pm 0.20$ & $4.95 \pm 0.13$ \\
\hline Chlorine (mEquiv./L) & $109.00 \pm 1.00$ & $102.33 \pm 1.53$ & $101.00 \pm 3.00$ \\
\hline Potassium (mEquiv./L) & $4.17 \pm 0.15$ & $4.50 \pm 0.10$ & $4.90 \pm 0.20$ \\
\hline Sodium (mEquiv./L) & $142.33 \pm 1.53$ & $143.00 \pm 3.00$ & $142.33 \pm 0.58$ \\
\hline Total cholesterol (mg/dL) & $76.00 \pm 1.73$ & $76.00 \pm 2.00$ & $84.00 \pm 1.00$ \\
\hline Triglycerides $(\mathrm{mg} / \mathrm{dL})$ & $83.00 \pm 4.36$ & $88.00 \pm 1.73$ & $97.33 \pm 8.96$ \\
\hline HDL-Cholesterol (mg/dL) & $37.33 \pm 2.08$ & $42.00 \pm 1.00$ & $45.00 \pm 1.00$ \\
\hline LDL-Cholesterol (mg/dL) & $18.00 \pm 5.57$ & $21.73 \pm 4.98$ & $16.63 \pm 1.07$ \\
\hline
\end{tabular}

Table 6: biochemical profile of female rats after 28 days consecutive administration of extract

\begin{tabular}{l|l|l|l}
\hline Parameters & Control & DD $250 \mathrm{mg} / \mathrm{kg}$ & DD $500 \mathrm{mg} / \mathrm{kg}$ \\
\hline Urea $(\mathrm{mg} / \mathrm{dL})$ & $63.06 \pm 8.33$ & $63.26 \pm 9.02$ & $57.94 \pm 8.85$ \\
\hline GGlycaemia $(\mathrm{mg} / \mathrm{dL})$ & $101.98 \pm 20.46$ & $118.09 \pm 1.58$ & $123.25 \pm 18.10$ \\
\hline Creatinin $(\mathrm{mg} / \mathrm{dL})$ & $5.62 \pm 0.12$ & $4.50 \pm 0.74$ & $4.97 \pm 0.05$ \\
\hline Uric Acid (mg/dL) & $4.10 \pm 1.35$ & $4.69 \pm 0.01$ & $5.17 \pm 1.00$ \\
\hline GOT (IU/L) & $91.48 \pm 16.96$ & $89.20 \pm 15.88$ & $100.12 \pm 29.32$ \\
\hline GPT (IU/L) & $93.52 \pm 10,43$ & $64.73 \pm 4.41$ & $76.12 \pm 16.05$ \\
\hline GGT (IU/L) & $1.97 \pm 0.58$ & $3.49 \pm 1.81$ & $5.28 \pm 2.47^{*}$ \\
\hline Pal (IU/L) & $411.57 \pm 0.47$ & $359.43 \pm 28.48$ & $398.77 \pm 9.36$ \\
\hline Total bilirubin (mg/dL) & $0.64 \pm 0.06$ & $0.80 \pm 0.03$ & $0.79 \pm 0.01$ \\
\hline Direct bilirubin (mg/dL) & $0.35 \pm 0.07$ & $0.45 \pm 0.07$ & $0.41 \pm 0.01$ \\
\hline Total protein (g/dL) & $6.05 \pm 0.07$ & $6.90 \pm 0.14$ & $6.55 \pm 0.78$ \\
\hline Albumin (g/dL) & $4.88 \pm 0.18$ & $4.93 \pm 0.25$ & $4.75 \pm 0.35$ \\
\hline Chlorine (mEquiv./L) & $99.50 \pm 2.12$ & $105.00 \pm 1.41$ & $104.00 \pm 5.66$ \\
\hline Potassium (mEquiv./L) & $4.10 \pm 0.14$ & $4.25 \pm 0.07$ & $4.25 \pm 0.07$ \\
\hline Sodium (mEquiv./L) & $139.50 \pm 0.71$ & $141.50 \pm 0.71$ & $142.50 \pm 3.54$
\end{tabular}




\begin{tabular}{l|l|l|l}
\hline Total cholesterol $(\mathrm{mg} / \mathrm{dL})$ & $71.50 \pm 9.19$ & $76.50 \pm 3.54$ & $77.00 \pm 2,83$ \\
\hline Triglycerides $(\mathrm{mg} / \mathrm{dL})$ & $87.50 \pm 3.54$ & $82.00 \pm 4.24$ & $92.00 \pm 8.49$ \\
\hline HDL-Cholesterol $(\mathrm{mg} / \mathrm{dL})$ & $36.50 \pm 2.12$ & $41.50 \pm 0.71$ & $44.50 \pm 0.71$ \\
\hline LDL-Cholesterol $(\mathbf{m g} / \mathrm{dL})$ & $\mathbf{1 7 . 5 0 \pm 7 . 7 8}$ & $\mathbf{2 4 . 6 0 \pm 0 . 5 7 ^ { * }}$ & $\mathbf{1 4 . 1 0 \pm 0 . 4 2 ^ { * }}$ \\
\hline
\end{tabular}

Effect of the extract on Streptozotocin diabetic induced rats

Glucose level : In order to evaluate the effect of the recipe on glucose homeostasis, the blood glucose level was measured every three days during treatment. The results of these measurements are shown in figures 3 and 4 , respectively, for male and female rats. It should be noted that there was no significant change in blood glucose for the control groups during the treatment. In the groups of rats treated with the extract as well as with the glibenclamide, there was a decrease and a normalization of the glycaemia. In the groups of male rats, after 16 days of treatment, the blood glucose returned to normal in those receiving the extract at 250 and $500 \mathrm{mg} / \mathrm{kg}$ body weight. However, it was after 25 days that it normalized for rats given glibenclamide $5 \mathrm{~m} /$ $\mathrm{kg}$. In the groups of female rats, the return to the normal value of blood glucose was around the 19th day for both the rats given the recipe and those receiving glibenclamide.

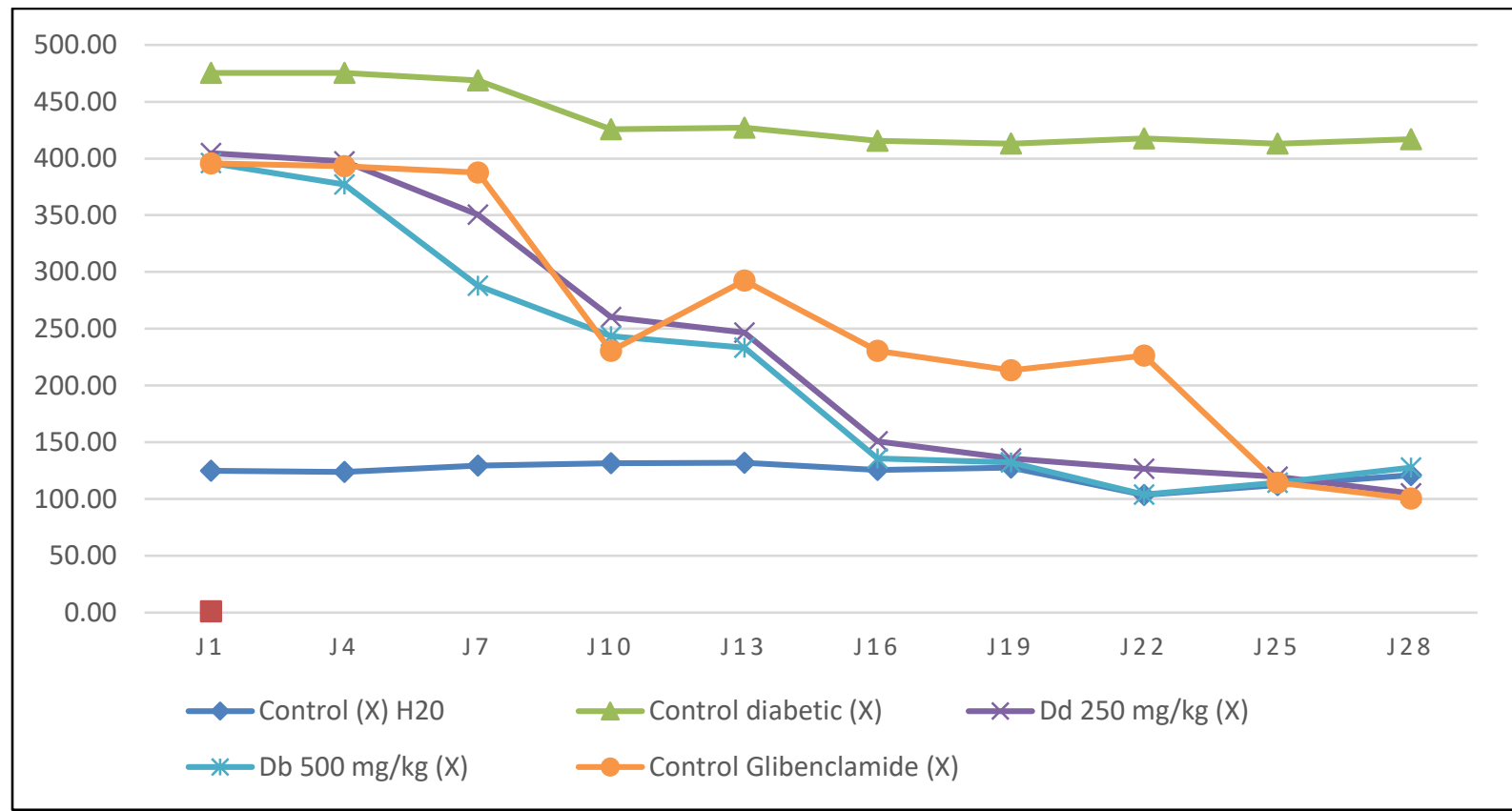

Figure 3: Blood glucose levels in normal and experimental groups of male rats 


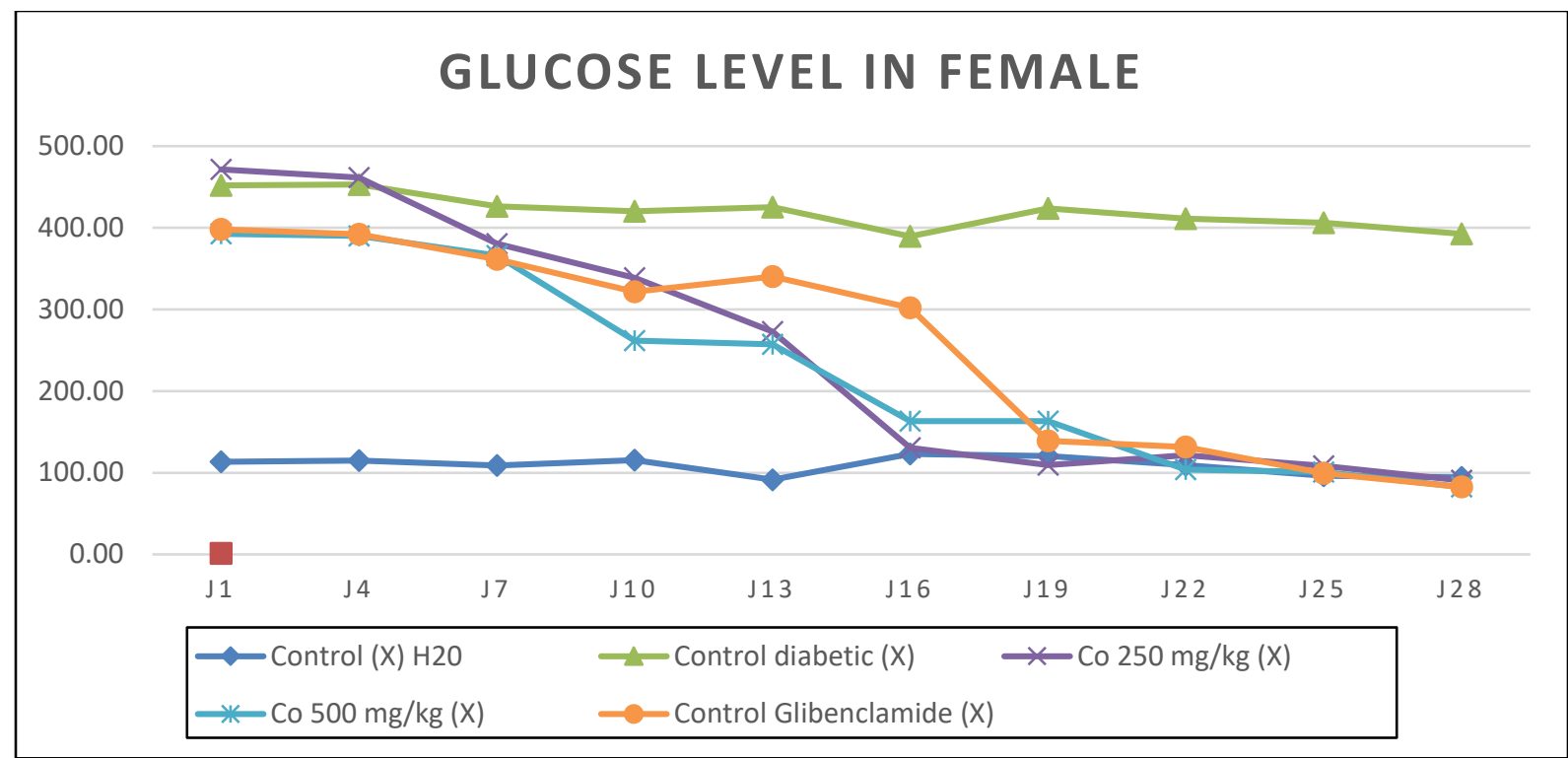

Figure 4: Blood glucose levels in normal and experimental groups of female rats

Effect the extract on biochemical parameters of diabetic rats : The biochemical profile of treated rats and control rats on day 28 were summarized in Tables 7 and 8 respectively for males and females. The measured parameters were; Glucose 6-phosphate dehydrogenase, glycated haemoglobin, amylase, lipase and serum lipids, namely total cholesterol, triglycerides, High density lipoproteins (HDL) and Low density lipoproteins (LDL). In both sexes, all parameters evaluated were above the norm in the groups of untreated diabetic rats $(P<0.0001)$ with the exception of the HDL for which there was no significant difference with the normal rats. Similarly, the $500 \mathrm{mg} / \mathrm{kg}$ dose of the recipe was the dose at which all measured parameters were not statistically different from the values measured for normal rats given distilled water. The dose of $250 \mathrm{mg} / \mathrm{kg}$ succeeded in normalizing the following parameters: glycated haemoglobin, total cholesterol, triglycerides and LDL in both males and females. However, the values recorded are significantly different from untreated diabetic rats; this suggests that the action of the recipe may be dose-dependent. With glibenclamide, only triglycerides did not return to normal value in both sexes. 
Table 7: Biochemical profile of treated diabetic male rats

\begin{tabular}{|c|c|c|c|c|c|c|c|c|}
\hline Groups & $\begin{array}{c}\text { G6PD (U/g } \\
\mathrm{Hb})\end{array}$ & HBA1 (\%) & $\begin{array}{c}\text { Amylase } \\
\text { (U/I) }\end{array}$ & $\begin{array}{c}\text { Lipase } \\
\text { (U/I) }\end{array}$ & $\begin{array}{c}\text { Total cholesterol } \\
(\mathrm{mg} / \mathrm{dL})\end{array}$ & $\begin{array}{l}\text { Triglycerides } \\
\text { (mg/dL) }\end{array}$ & $\begin{array}{c}\text { HDL-Cholesterol } \\
\text { (mg/dL) }\end{array}$ & $\begin{array}{l}\text { LDL-Cholesterol } \\
\text { (mg/dL) }\end{array}$ \\
\hline Control $\mathrm{H}_{2} \mathrm{O}$ & $12.53 \pm 0.06$ & $5.7 \pm 0.10$ & $\begin{array}{c}122.33 \pm 2 . \\
08\end{array}$ & $34.67 \pm 0.58$ & $76 \pm 1.73$ & $83 \pm 4.36$ & $37.33 \pm 2.08$ & $18 \pm 5.57$ \\
\hline $\begin{array}{c}\text { Control } \\
\text { Diabetics }\end{array}$ & $\underset{* \star}{3.47 \pm 0.06^{*}}$ & $\begin{array}{c}13.67 \pm 0.5 \\
8^{\star \star \star}\end{array}$ & $\underset{* *}{265 \pm 5.57^{*}}$ & $\begin{array}{c}165.33 \pm 2.3 \\
1^{* \star \star}\end{array}$ & $166.33 \pm 12.66^{* *}$ & $198,33 \pm 8.33^{* \star *}$ & $26.33 \pm 3.21$ & $100.33 \pm 16.61^{* * \star}$ \\
\hline $\begin{array}{c}\mathrm{DD} 250 \\
\mathrm{mg} / \mathrm{kg}\end{array}$ & $6 \pm 0.10^{* *}$ & $6.33 \pm 0.58$ & $\begin{array}{c}200.33 \pm 0 . \\
58^{*}\end{array}$ & $66 \pm 19.08^{*}$ & $76 \pm 2.0$ & $88 \pm 1.73$ & $42 \pm 1.0$ & $18.4 \pm 5.05$ \\
\hline $\begin{array}{l}\mathrm{DD} 500 \\
\mathrm{mg} / \mathrm{kg}\end{array}$ & $7.47 \pm 0.32$ & $5.67 \pm 0.58$ & $\begin{array}{c}164.33 \pm 0 . \\
58\end{array}$ & $38.13 \pm 0.64$ & $74 \pm 13.35$ & $97.33 \pm 8.96$ & $45 \pm 1.0$ & $16.63 \pm 1.07$ \\
\hline $\begin{array}{c}\text { Glibenclamid } \\
\mathrm{e}\end{array}$ & $7 \pm 0.53$ & $7 \pm 1.0$ & $173 \pm 2.65$ & $\begin{array}{c}66.13 \pm 0.92 \\
*\end{array}$ & $99.67 \pm 1.53$ & $149.33 \pm 15.01^{* *}$ & $37.67 \pm 2.52$ & $32.13 \pm 4.0$ \\
\hline
\end{tabular}

${ }^{*}$ Different from control $\mathrm{H}_{2} \mathrm{O}$ at $\mathrm{P}<0.05$

${ }^{*}$ Different from control $\mathrm{H}^{2} \mathrm{O}$ at $\mathrm{P}<0.001$

${ }^{* * *}$ Different from control $\mathrm{H}_{2} \mathrm{O}$ at $\mathrm{P}<0.0001$

Table 8: Biochemical profile of treated diabetic female rats

\begin{tabular}{|c|c|c|c|c|c|c|c|c|}
\hline Groups & $\begin{array}{l}\text { G6PD (U/g } \\
\mathrm{Hb}) /\end{array}$ & $\begin{array}{l}\text { HBA1 } \\
(\%)\end{array}$ & $\begin{array}{l}\text { Amylasemia } \\
(\mathrm{U} / \mathrm{I})<220\end{array}$ & lipase & $\begin{array}{l}\text { Total cholesterol } \\
(\mathrm{mg} / \mathrm{dL})\end{array}$ & $\begin{array}{l}\text { Triglycerides } \\
\text { (mg/dL) }\end{array}$ & $\begin{array}{l}\text { HDL-Cholesterol } \\
\text { (mg/dL) }\end{array}$ & $\begin{array}{l}\text { LDL-Cholesterol } \\
\text { (mg/dL) }\end{array}$ \\
\hline $\begin{array}{l}\text { Control } \\
\mathrm{H}_{2} \mathrm{O}\end{array}$ & $12.35 \pm 0.49$ & $6 \pm 0.0$ & $122 \pm 2.83$ & $\begin{array}{l}34.5 \pm 0.7 \\
1\end{array}$ & $75.33 \pm 2.52$ & $87.33 \pm 2.52$ & $36.67 \pm 1.53$ & $21.2 \pm 2.31$ \\
\hline $\begin{array}{l}\text { Control } \\
\text { diabetic }\end{array}$ & $\begin{array}{l}3.45 \pm 0.21^{* *} \\
*\end{array}$ & $12 \pm 0.0$ & $290 \pm 14.14^{* \star \star}$ & $\begin{array}{l}165 \pm 7.0 \\
7^{* * *}\end{array}$ & $170.67 \pm 11.02^{* \star *}$ & $198.33 \pm 8.33^{* *}$ & $24 \pm 2$ & $107 \pm 14,64^{* * *}$ \\
\hline $\begin{array}{ll}\mathrm{DD} & 250 \\
\mathrm{mg} / \mathrm{kg} & \\
\end{array}$ & $6 \pm 0.42^{* *}$ & $7 \pm 0.0$ & $185 \pm 7.07^{*}$ & $88 \pm 5.6^{\star \star}$ & $75.67 \pm 2.89$ & $80.33 \pm 9.87$ & $41.33 \pm 0.58$ & $21.13 \pm 5.31$ \\
\hline $\begin{array}{ll}\mathrm{DD} & 500 \\
\mathrm{mg} / \mathrm{kg} & \end{array}$ & $7.5 \pm 0.0$ & $5 \pm 0.0$ & $164.5 \pm 2.12$ & $38 \pm 1.41$ & $79.67 \pm 5.03$ & $90.33 \pm 6.66$ & $44.67 \pm 0.58$ & $14.87 \pm 1.36$ \\
\hline $\begin{array}{l}\text { Glibenclami } \\
\text { de }\end{array}$ & $8 \pm 0.14$ & $\begin{array}{l}5.5 \pm 0.7 \\
1\end{array}$ & $171 \pm 1.41$ & $66 \pm 2.83$ & $108.67 \pm 1.15^{\star *}$ & $156 \pm 7.21^{* *}$ & $36 \pm 2.0$ & $41.47 \pm 2.05$ \\
\hline
\end{tabular}

${ }^{*}$ Different from control $\mathrm{H}_{2} \mathrm{O}$ at $\mathrm{P}<0.05$

${ }^{* *}$ Different from control $\mathrm{H}_{2} \mathrm{O}$ at $\mathrm{P}<0.001$

${ }^{* * \star}$ Different from control $\mathrm{H}_{2} \mathrm{O}$ at $\mathrm{P}<0.0001$ 


\section{DISCUSSION}

The main objective of this study was to evaluate the antidiabetic effects of the ethanolic extract of the Diabeto-Dolvo® recipe on STZ induced diabetic rats. In the first part, the phenolic content of the recipe and its free radical scavenging activity was investigated. Phenolic compounds are agents present in all plants and well known for their antioxidant activity. This property is useful in the use of medicinal plants, as free radicals are incriminated in the occurrence of many diseases, including diabetes. This study results showed that the DD recipe is very rich in phenolic compounds and that these give it an antioxidant capacity equivalent to 111.51 $\pm 0.42 \mathrm{mg}$ of ascorbic acid per gram of extract. This scavenging ability can contribute to reduce the oxidative stress that occurs in diabetes attacks. In fact, the results of the biochemical analyses showed that G6PD, decreased significantly in treated diabetic rats. It evidence that the recipe DD has an antioxidant effect but the current data do not allow linking the reduction of the rate of G6PD to the phenolic compounds. Subsequently, the acute toxicity and subacute toxicity of the extract were assessed in the rats. The results of these tests showed that, overall, the recipe can be considered nontoxic. However, there may be slight interference with liver function due to increased GGT. It is the first time that this plant combination is tested for its toxicity, however all the plants of the combination have already been tested singularly. Thus, in the case of Phyllanthus niruri, Asare et al. (2011) showed that the plant is not toxic on rats. In this plant, protective effects have been described (Amin et al., 2012; Ho et al., 2012). Similarly, for Momordica charantia, Abd El Sattar El Batran et al. (2006) showed that peritoneal injection of plant leaf extract did not affect biochemical parameters such as creatinine, alkaline phosphatase, transaminases and urea. They concluded that the extract had a reno hepatoprotective effect. However, a previous study showed that seeds and fruit juices contain hepatotoxins that can cause tissue damage (Tennekoon et al., 1994). Thus, for most of these authors, it is mainly the fruit and the seeds that are toxic, the leaf extract would be less. In contrast to these two plants, Xylopia aethiopica, showed a cytotoxic effect by inhibiting mitochondrial respiration (Choumessi et al., 2012). The same is true for Caesalpinia bunduc because the alcoholic extract of the plant has proven toxicity in rats according to the study of Ogunlana et al. (2013). Extensive studies have shown that the cytotoxic effect of the plant is mainly due to flavonoids (Ogunlana et al., 2015). From this study, the combination of plants had beneficial effect because they were less toxic than plants taken singularly. Streptozotocin is a well-known agent for type I diabetes induction via pancreatic $\beta$ cells destruction. Consequently, in this type of diabetes, insulin is not totally absent but its secretion is not sufficient (Kedar and Chakrabarti, 1982). Glibenclamide used as a standard antidiabetic agent has also been reported as a hypoglycaemic agent in STZ-induced diabetic rats (Cheeseman and Slater, 1993; Andrade Cetto et al., 2000). Sulfonylureas such as glibenclamide have as a mode of action the stimulation of insulin secretion by pancreatic $\beta$ cells mainly by the inhibition of KATP channels of sensitive ATP in the plasma membrane (Courtois et al., 2003). In the present study, the administration of extract induced a significant decrease of blood glucose and lipids. Hence, the probable mode of action of the extracts may the stimulation of the surviving Langerhans $\beta$ cells to produce more insulin (Pari and Latha, 2002). The four plants of the recipe have been singularly tested for their antidiabetic properties in several previous studies. Phyllanthus niruri has hypolipidemic and hypoglycaemic effects known through several studies (Mediani et al., 2016; Giribabu et al., 2014, 2017). The same is true for Xylopia aethiopica, but this plant has mainly been tested in models of type 2 diabetes (Adefegha and Oboh, 2012; Okpashi et al., 2014; Mohammed et al., 2016). Jana et al. (2012) also demonstrated the hypoglycaemic activity of Caesalpinia bunduc. Of the four plants in the recipe, the one that received most attention for its antidiabetic activity is Momordica charantia. Several aspects of the disease have been tested (Yousaf et al., 2016; Mahmoud et al., 2017). Nowadays it is known that charantin, isolated from the plant is responsible for its hypoglycaemic activity. Moreover, this molecule also contributes to the haemoglobin antiglycosylation (Aljohi et al., 2016). A second molecule isolated from the plant, cucurbitane would have a similar activity (Jiang et al., 2016). It is also known that polysaccharides of the plant also contribute in this activity (Raish, 2016). This study showed that levels of glucose, total cholesterol, triglycerides, LDL cholesterol, amylase and lipase were significantly higher in diabetics $(p<0.05)$ than in treated rats. There were significant positive correlations between glucose and total cholesterol, triglycerides, amylase and lipase, while significant negative correlations were obtained between glucose and glycated haemoglobin and G6PD. These results are therefore in agreement with the previous studies on the antidiabetic activity of plants. However, there were no indications of such results. Indeed, in the combinations, 
there are some that are antagonistic and this results in a loss of the desired activity. The current data do not allow us to state exactly how the combination works, so it can be an addition or a synergy. However, it is important to note that the extract has been successful in normalizing

\section{CONCLUSION AND APPLICATION OF RESULTS}

The issue of this study revealed that the DD recipe in addition to being non-toxic succeeded in reducing and normalizing the glucose level and the lipid profile. Similarly, oxidative stress was reduced in these rats similarly to glibenclamide. These results demonstrated disturbed parameters in a mode similar to glibenclamide, the reference drug used in this study. Another beneficial effect of the recipe is that it is less toxic than plants taken singularly, so the combination has had the effect of reducing the toxicity of the recipe.

the relevance of traditional recipes and reiterated the need to focus on recipes screening in addition to the singularly screened plants. This constitutes an experimental validation of the medicinal heritage of Togo.

Acknowledgements: The authors are grateful to all the traditional practitioners of the maritime region of Togo who accepted to participate to this study.

Conflict of interest: we declare no conflict of interest.

\section{REFERENCES}

WHO Diabetes 2017. http://www.who.int/mediacentre/ factsheets/fs312/en/ [Accessed: 12-May-2017]

Alamdari DH, Aghasizadeh-Sharbaf M, Mohadjerani M, Ferns GA, Avan A Prooxidant-antioxidant balance and antioxidant properties of Thujaorientalis L: a potential therapeutic approach for diabetes mellitus. Curr Mol Pharmacol 2017; 10.

Johar DR, Bernstein LH Biomarkers of stress-mediated metabolic deregulation in diabetes mellitus. Diabetes Res Clin Pract 2017; 126: 222-229.

Yazdanpanah S, Rabiee M, Tahriri M, Abdolrahim M, Rajab A, Jazayeri HE, Tayebi L. Evaluation of glycated albumin $(\mathrm{GA})$ and $\mathrm{GA} / \mathrm{HbA} 1 \mathrm{c}$ ratio for diagnosis of diabetes and glycaemic control: a comprehensive review. Critical Rev Clin Lab Sci 2017; 54 (4): 219-232.

Porqueddu T. Herbal medicines for diabetes control among Indian and Pakistani migrants with diabetes. Anthropol Med 2017; 24 (1): 17-31.

Karou SD, Tchacondo T, Tchibozo MAD, AbdoulRahaman S, Anani K, Koudouvo K, Batawila K, Agbonon A, Simpore J, and de Souza C. Ethnobotanical study of medicinal plants used in the management of diabetes mellitus and hypertension in the Central Region of Togo. Pharm Biol 2011; 49 (12): 1286-1297.

Gbekley EH, Karou DS, Gnoula C, Agbodeka K, Anani K, Tchacondo T, Simpore J. Ethnobotanical study of plants used in the treatment of diabetes in the traditional medicine of Maritime Region, Togo. Pan Afr Med J 2015; 20: 437-452.

Giribabu N, Kumar KE, Rekha SS, Muniandy S, Salleh
N. Chlorophytum borivilianum root extract maintains near normal blood glucose, insulin and lipid profile levels and prevents oxidative stress in the pancreas of streptozotocininduced adult male diabetic rats. Int J Med Sci 2014; 11 (11): 1172-1184.

Attanayake AP, Jayatilaka KAPW, Pathirana C, Mudduwa LKB (2016) Gmelina arborea Roxb. Extract Upregulates the $\beta$-Cell Regeneration in STZ Induced Diabetic Rats. J Diabetes Res 2016; 4513871.

Oguntibeju OO, Meyer S, Aboua YG, Goboza M. Hypoxishemerocallidea Significantly Reduced Hyperglycaemia and Hyperglycaemic-Induced Oxidative Stress in the Liver and Kidney Tissues of Streptozotocin-Induced Diabetic Male Wistar Rats. Evid Based Complement Alternat Med 2016; 8934362.

Leonti M, Stafford GI, Cero MD, Cabras S, Castellanos ME, Casu L, Weckerle CS. Reverse ethnopharmacology and drug discovery. J Ethnopharmacol 2017; 198: 417-431.

Calcabrini C, De Bellis R, Mancini U, Cucchiarini L, Stocchi V, Potenza L. Protective Effect of Juglans regia L. Walnut Extract Against Oxidative DNA Damage. Plant Foods Hum Nutr 2017; 72(2): 192-197.

Sabu MC, Kuttan R. Anti-diabetic activity of medicinal plants and its relationship with their antioxidant property. J Ethnopharmacol 2002; 81 (2): 155160.

Kpodar MS, Karou SD, Katawa G, Anani K, Gbekley EH, Adjrah Y, Tchacondo T, Batawila K, Simpore J. 
An ethnobotanical study of plants used to treat liver diseases in the Maritime region of Togo. $\mathrm{J}$ Ethnopharmacol 2016; 181: 263-273.

Edorh MS, Agbere S, Osei-Safo D, Adam Z, Agbonon A, Karou DS, Agbere RA, Gbeassor M. Toxicological screening of Daouri, a polyherbal formulation used in children in the Central Region of Togo. J Ethnopharmacol 2015; 164: 30-34.

Ahama-Esseh K, Bodet C, Quashie-Mensah-Attoh A, Garcia M, Théry-Koné I, Dorat J, De Souza C, Enguehard-Gueiffier C, Boudesocque-Delaye L. Anti-inflammatory activity of Crateva adansonii DC on keratinocytes infected by Staphylococcus aureus: From traditional practice to scientific approach using HPTLCdensitometry. J Ethnopharmacol 2017; 204: 2635.

Gbekley HE, Soncy K, Karou DS, Djéri B, Agbodéka K, Ameyapoh B, Jacques $S$, de Souza CA, and Gbeassor M. Assessment of hygienic quality of some antidiabetic recipes. Int J Innov Applied Studies 2017; 19 (4) :824-838.

Singleton SL, Orthofer VL, Lamuela-Raventós RM. Analysis of total phenolics and other oxidation substrates and antioxidants by means of FolinCiocalteu reagent. In: Lester Packer éditors. Methods in Enzymology. Oxidants and Antioxidants, Part A. San Diego: Elsevier 1999; 299:152-178.

Makkar HP. Quantification of Tannins in Tree Foliage: A Laboratory Manual for the FAO/IAEA Coordinated Research Project on Use of Nuclear and Related Techniques to Develop Simple Tannins Assay for Predicting and Improving the Safety and Efficiency of Feeding Ruminants on the Tanniferous Tree Foliage. Joint FAO/IAEA Division of Nuclear Techniques in Food and Agriculture, editors. Vienna, Austria; 1999.

Prieto $P$, Pineda M, Aguilar M. Spectrophotometric quantification of antioxidant capacity through the formation of a phosphomolybdenum complex: specific application of vitamin $E$ analytical. Biochem 1999; 269: 337-341.

Guide for the Care and Use of Laboratory Animals, 8th Edition, prepublication copy - Guide-for-theCare-and-Use-of-Laboratory-

Animals_Prepub.pdf. [Accessed: 12-May2017]. Available: https://grants.nih.gov/grants/olaw/Guide-forthe-Care-and-Use-of-Laboratory-
Animals_Prepub.pdf.

Asare GA, Addo P, Bugyei K, Gyan B, Adjei S, OtuNyarko LS, Wiredu EK, Nyarko A. Acute toxicity studies of aqueous leaf extract of Phyllanthus niruri. Interdiscip Toxicol 2011; 4 (4): 206-210.

Amin ZA, Bilgen M, Alshawsh MA, Ali HM, Hadi AHA, Abdulla MA. Protective Role of Phyllanthus niruri Extract against Thioacetamide-Induced Liver Cirrhosis in Rat Model. Evid Based Complement Alternat Med 2012; 241583.

Ho WY, Yeap SK, Ho CL, Abdul Rahim R, Alitheen NB. Hepatoprotective Activity of Elephantopus scaber on Alcohol-Induced Liver Damage in Mice. Evid Based Complement Alternat Med 2012; 417953.

Abd El Sattar El Batran S, El-Gengaihi SE, El Shabrawy OA. Some toxicological studies of Momordica charantia L. on albino rats in normal and alloxan diabetic rats," J Ethnopharmacol 2006; 108 (2): 236-242.

Tennekoon KH, Jeevathayaparan S, Angunawala $\mathrm{P}$, Karunanayake $\mathrm{EH}$, Jayasinghe KS. Effect of Momordica charantia on key hepatic enzymes. J Ethnopharmacol 1994; 44 (2): 93-97.

Choumessi AT, Loureiro R, Silva AM, Moreira AC, Pieme AC, Tazoacha A, et al. Toxicity evaluation of some traditional African spices on breast cancer cells and isolated rat hepatic mitochondria. Food Chem. Toxicol 2012; 50 (11): 4199-4208.

Ogunlana OO, Ogunlana $O E$, Adeneye $A A$, UdoChijioke OAC, Dare-Olipede TI, Olagunju JA, et al. Evaluation of the toxicological profile of the leaves and young twigs of Caesalpinia bonduc (Linn) roxb. Afr J Tradit Complement Altern Med 2013; 10 (6): 504-512.

Ogunlana OO, He WJ, Fan JT, Zeng GZ, JI CJ, Zheng $\mathrm{YQ}$, Olagunju JA, Akindahunsi AA and Tan NH. Report: Cytotoxic flavonoids from the young twigs and leaves of Caesalpinia bonduc (Linn) Roxb. Pak J Pharm Sci 2015; 28 (6) : 21912198.

Kedar P, Chakrabarti $\mathrm{CH}$. Effects of bittergourd (Momordica charantia) seed \& glibenclamide in streptozotocin induced diabetes mellitus. Indian J Exp Biol 1982; 20 (3): 232-235.

Andrade Cetto A, Wiedenfeld H, Revilla MC, Sergio IA. Hypoglycaemic effect of Equisetum myriochaetum aerial parts on streptozotocin diabetic rats. J Ethnopharmacol 2000; 72 (1-2): 129-133. 
Cheeseman KH, Slater TF. An introduction to free radical biochemistry. Br Med Bull 1993; 49 (3): 481493.

Courtois P, Jijakli H, Ladriere L, Oguzhan B, Sener A, Malaisse WJ. Pharmcodynamics, insulinotropic action and hypoglycaemic effect of nateglinide and glibenclamide in normal and diabetic rats. International J Mol Med 2003; 11 (1): 105-109

Pari L, Latha M. Effect of Cassia auriculata flowers on blood sugar levels, serum and tissue lipids in streptozotocin diabetic rats. Singapore Med J 2002; 43 (12): 617-621.

Mediani A, Abas F, Maulidiani M, Khatib A, Ping Tan C, Ismail IS, Shaarib $\mathrm{K}$, Ismail A, Lajis $\mathrm{NH}$. Metabolic and biochemical changes in streptozotocin induced obese-diabetic rats treated with Phyllanthus niruri extract. J Pharm Biomed Anal 2016; 128: 302-312.

Giribabu N, Rao PV, Kumar KP, Muniandy S, Rekha SS, Salleh N. Aqueous Extract of Phyllanthus niruri Leaves Displays In Vitro Antioxidant Activity and Prevents the Elevation of Oxidative Stress in the Kidney of Streptozotocin-Induced Diabetic Male Rats. Evid Based Complement Alternat Med 2014; 834815.

Giribabu N, Karim K, Kilari EK, Salleh N. Phyllanthus niruri leaves aqueous extract improves kidney functions, ameliorates kidney oxidative stress, inflammation, fibrosis and apoptosis and enhances kidney cell proliferation in adult male rats with diabetes mellitus. J Ethnopharmacol 2017; 205: 123-137.

Adefegha SA, Oboh G (2012) Inhibition of key enzymes linked to type 2 diabetes and sodium nitroprusside-induced lipid peroxidation in rat pancreas by water extractable phytochemicals from some tropical spices. Pharm Biol 50 (7): 857-865.

Okpashi VE, Bayim BPR, Obi-Abang M. Comparative Effects of Some Medicinal Plants: Anacardium occidentale, Eucalyptus globulus, Psidium guajava, and Xylopia aethiopica Extracts in Alloxan-Induced Diabetic Male Wistar Albino Rats. Biochem Res Int 2014: 203051.

Mohammed A, Koorbanally NA, Islam MS. Anti-diabetic effect of Xylopia aethiopica (Dunal) A. Rich. (Annonaceae) fruit acetone fraction in a type 2 diabetes model of rats. J Ethnopharmacol 2016; 180: 131-139.

Jana K, Chatterjee K, Ali KM, De D, Bera TK, Ghosh D. Antihyperglycemic and antioxidative effects of the hydro-methanolic extract of the seeds of Caesalpinia bonduc on streptozotocin-induced diabetes in male albino rats. Pharmacognosy Res 2012; 4 (1): 57-62.

Yousaf S, Hussain A, Rehman S, Aslam MS, Abbas Z. Hypoglycaemic and hypolipidemic effects of Lactobacillus fermentum, fruit extracts of Syzygiumcumini and Momordica charantia on diabetes induced mice. Pak J Pharm Sci 2016; 29 (5): 1535-1540.

Mahmoud MF, El Ashry FEZZ, El Maraghy NN, Fahmy A. Studies on the antidiabetic activities of Momordica charantia fruit juice in streptozotocin-induced diabetic rats. Pharm Biol 2017; 55 (1): 758-765.

Aljohi A, Matou-Nasri S, Ahmed N. Antiglycation and Antioxidant Properties of Momordica charantia. PLOS ONE 2016; 11 (8):0159985.

Jiang B, Ji M, Liu W, Chen L, Cai Z, Zhao Y, Bi X. Antidiabetic activities of a cucurbitane-type triterpenoid compound from Momordica charantia in alloxan-induced diabetic mice. Mol Med Rep 2016; 14 (5): 4865-4872.

Raish M, Ahmad A, Jan BL, Alkharfy KM, Ansari MA, Mohsin K, Al-Jenoobi F, Al-Mohizea A. Momordica charantia polysaccharides mitigate the progression of STZ induced diabetic nephropathy in rats. Int J Biol Macromol 2016; 91: 394-399. 